\title{
İnformasiya təhlükəsizliyinin menecmenti standartlarının əlaqəli standartlarla harmonizasiyası xəritəsi: təkliflər
}

\author{
Elçin Oliyev $^{1}$, Yadigar İmamverdiyev ${ }^{2}$ \\ AMEA İnformasiya Texnologiyaları İnstitutu, Bakı, Azərbaycan \\ ${ }^{1}$ elchinaa@gmail.com, ${ }^{2}$ yadigarelan.ab.az
}

\begin{abstract}
Xülasə- Bu məqalədə informasiya təhlükəsizliyinin menecmenti standarlarının vo sisteminin digər sahələrin menecment standartları vo sistemləri arasında koordinasiya məsələləri qoyulur. Bunun üçün informasiya təhlükəsizliyinin və digər əlaqəli sahələrin menecment standartları identifikasiya edilir; bu menecment prosesləri PDCA modeli üzrə təsnifatlaşdırılır; informasiya təhlükəsizliyinin menecmenti standarlarının əlaqəli standartlarla harmonizasiyası, o cümlədən səbəb-nəticə asılılıqları, terminoligiyada uyğunsuzluqlar barədə problemlər qoyulur; “ISMS” (ISO/IEC-27001) və “SMS” (ISO/IEC-20000) arasında "maraqların münaqişəsi”"nin "maraqların uzlaşdırılması"na transferi məsələsi üçün həll variantları verilir.
\end{abstract}

Açar sözlor - informasiya tohlükosizliyi; menecment sistemi; menecment standartları; PDCA modeli; prosesli yanaşma; standartların harmonizasiyası; ümumi kordinasiya

\section{GİRIŞ}

İnformasiya təhlükəsizliyi bir praktiki fəaliyyət sahəsi və bir elmi tədqiqat istiqaməti kimi son bir neçə onillikdə formalaşmışdır. İlkin yanaşmalarda hansısa bir texniki həll vasitəsi ilə problemləri həll etməyə çalışırdılar, həllər çoxaldıqca informasiya təhlükəsizliyinin təmin edilməsinə kompleks yanaşma meydana çıxdı. Tezliklə bu yanaşmanın da problemi həll edə bilmədiyi aydınlaşdı. Hazırda əsas yanaşma informasiya tohlükasizliyinin menecmenti paradiqmasıdır.

Bu paradiqmada əsas ideya informasiya təhlükəsizliyinə sistemin keyfiyyət göstəricisi kimi baxmaqdır. Keyfiyyəti idarə etmək mümkündür, deməli, təhlükəsizliyi də idarə etmək olar. $\mathrm{Bu}$ yanaşmada informasiya təhlükəsizliyi sisteminin əsas komponenti kimi texniki aspektlər deyil, menecment komponentləri götürülür.

İnformasiya təhlükəsizliyinin menecmentini optimal necə həyata keçirmək olar? Müəyyən mənada optimal yanaşma ən yaxşı təcrübədən istifadə etməkdir. Standartlaşdırma təşkilatları informasiya təhlükəsizliyi sahəsində ən yaxşı təcrübələri 1990c1 illərdən beynəlxalq standartlar kimi qəbul etməyə başlamışlar. Məlumdur ki, ISO/IEC-2700* standartlar ailəsi və ISO-9001 standartı informasiya təhlükəsizliyinin menecmenti üçün təşkiledici standarlardır.

\section{II. İNFORMASIYA TӘHLÜKӘSIZLIYIININ MENECMENT ELEMENTLӘRI}

ISO/IEC-27001 standartında populyar “Annex $A$ ” (OlavəA) informasiya təhlükəsizliyinin menecment elementi olan məqsədləri (gözləntiləri, "objective”) və realizasiya üsullarını (təhlükəsizlik alətlərini) müəyyən edir və onları bir neçə bölmə üzrə qruplaşdırır:

(A.5) İnformasiya təhlükəsizliyi siyasətləri - təşkilatın rəhbərliyi tərəfindən informasiya təhlükəsizliyi sahəsində siyasətin dəstəklənməsi;

(A.6) İnformasiya təhlükəsizliyinin təşkili - təşkilatda informasiya təhlükəsizliyi sisteminin iş qabiliyyətini təmin edəcək təşkilati strukturun yadradılması;

(A.7) İnsan resurslarının təhlükəsizliyi - insan səhvləri riskinin, oğurluğun və avadanlığın qeyri-düzgün istifadəsinin azaldılması (əməkdaşların təlimi və insidentlərin izlənməsi);

(A.8) Aktivlərin (resursların) idarə edilməsi - informasiya resurslarına onların dəyər dərəcələrinə görə prioritet verilməsi və onlara görə məsuluyyətin paylanması;

(A.9) Girişə nəzarət - biznes-informasiyaya girişin idarə edilməsi;

(A.10) Kriptoqrafiya - şifrləmə və açarların idarə edilməsi sahəsində idarəetmə vasitələri

(A.11) Fiziki təhlükəsizlik və ətraf mühitin təhlükəsizliyi avtorizə olunmamış girişin və təşkilatın informasiya sisteminin işinin pozulmasının qarşısının alınması;

(A.12) Oməliyyatların təhlükəsizliyi - IT-sahənin idarə edilməsinə aid olan vasitələr: dəyişikliklərin idarə edilməsi, zərərli proqram təminatından mühafizə, ehtiyat surətlər, qeydiyyat, monitorinq, quraşdırma, boşluqlar və $\mathrm{s}$.

(A.13) Kommunikasiyaların təhlükəsizliyi - şəbəkələrin və kompüterlərin təhlükəsiz fəaliyyətinin təmin edilməsi;

(A.14) Sistemin alınması, yaradılması və istismarı təşkilatın informasiya sisteminin yaradılması və ya inkişafı zamanı informasiya təhlükəsizliyi tələblərinin 
yerinə yetirilməsi, tətbiqi proqramların və verilənlərin təhlükəsizliyinin dəstəklənməsi;

(A.15) Təchizatçılarla münasibətlər - təşkilatın təchizatçılara əlyetər informasiyasının təhlükəsizliyi məsələsini həll etməyə yönəlir; təchizatçılarla müqavilələrdə informasiya təhlükəsizliyinin nəzərə alınması və təchizatçıların monitorinqi

(A.16) İnformasiya təhlükəsizliyi insidentlərinin idarə edilməsi - informasiya təhlükəsizliyi hadisələri və nöqsanlar haqqında məlumatlandırma, vəzifələrin müəyyən edilməsi, insidentlərə reaksiya və sübutların toplanması prosedurları

(A.17) Fəaliyyətin fasiləsizliyinin təmin edilməsində informasiya təhlükəsizliyi aspektləri - fövqəladə hallarda təşkilatın fasiləsiz işinin təmin edilməsi üçün fəaliyyət planı;

(A.18) Qanunvericiliyin tələblərinə uyğunluq - müvafiq mülki və cinayət qanunvericiliyinin, müəllif hüquqları və informasiyanın mühafizəsi qanunları daxil olmaqla, tələblərinin yerinə yetirilməsi.

\section{III. İNFORMASIYA TӘHLÜKəSIZLIYIININ MENECMENT PROSESLORI}

ISO-9001 standartından başlayaraq, demək olar ki, bütün funksional fəaliyyət sahələrinin menecmentinə aid standartlarda menecment prosesləri spiralvari PDCA tsiklik modelinə (Deming-Shewhart cycle PDCA: "Initiating, Plan Do - Check - Act, Feedback”) uyğun müəyyən edilir.

ISO/IEC-27001 standartına görə informasiya təhlükəsizliyinin menecment prosesləri PDCA modelinə uyğun olaraq mərhələlər üzrə müəyyən edilir, biznesin menecment mərhələrinə inteqrasiya olunur:

\section{A. Biznesin funksional menecment modeli:}

1) Planlaşdırma, qarar qabuletmə:

- fəaliyyət imkanlarını və riskləri qiymətləndirmə;

- fəaliyyət proseslərini və fasiləsizlyini planlaşdırma, qərar qəbuletmə.

2) Ícra va qeydiyyat:

- resursları formalaşdırma;

- $\quad$ qərarları həyata keçirmə;

- nəticələri təqdimetmə, təhvilvermə;

- proses və nəticələrin, əks-əlaqə məlumatlarının qeydiyyati.

3) Nazarat va tahlil:

- $\quad$ qeydiyyatların monitorinqi;

- fəaliyyət sisteminin, komponentlərinin auditi;

- nəticələrin, vəziyyətin analizi və dəyərləndirmə.

4) Təkmilloşdirmo, aktuallaşdırma:

- fəaliyyət planını və proseslərini təkmilləşdirmək üçün təkliflərin verilməsi;

- fəaliyyət prosedurları üçün aktuallığın təmin edilməsi.
B. Informasiya tahlükəsizliyinin menecment modeli:

1) Planlaşdırma, qarar qabuletmə:

- İTİS üzrə fəaliyyət üçün məqsəd və vəzifələri, hədəfləri, tələbləri və etimad hədlərini, təhdidləri və zəiflikləri, riskləri və meyarları dəqiqləşdirmə, imkanları və riskləri qiymətləndirmə;

- İTÍS üzrə perspektiv və cari tədbirlər planlarını hazırlama.

2) Ícra va qeydiyyat:

- risklərə adekvat mühafizə üsulları və vasitələri ilə, kompetent işçi heyətlə təminat, texniki xidmət və maarifləndirmə;

- İTİS üzrə siyasət, prosedur, səlahiyyət bölgüsü və digər mühafizə üsullarını icraetmə, mühafizə hədəflərinə, risklərə, prosedurlara və vasitələrə aid reyestrləri istifadə və idarəetmə;

- informasiya təhlükəsizliyi üzrə hadisələrin müntəzəm qeydiyyatı, molumatlandirma.

3) Nazarat va tahlil:

- informasiya təhlükəsizliyi üzrə hadisələrin müntəzəm monitorinqi və auditi, insidentlərə cavabvermə və fəsadları ölcmə;

- uyğunsuzluqlar və səbəblərin təhlili, informasiya təhlükəsizliyi menecmentinin effektivliyini dəyərləndirmə.

4) Təkmilləşdirmə, aktuallaşdırma:

- $\quad$ qalıq riskləri müəyyənetmə, informasiya təhlükəsizliyi menecmentinin davamlı təkmilləşdirilməsi təshihedici və qabaqlayicı təklif vermə (IKKT-nin inkişaf intensivliyini, istifadəçilərin artan tələblərini nəzərə almaqla);

- mühafizə hədəflərinə, risklərə, prosedurlara və vasitələrə aid reyestrləri təkmilləşdirmə.

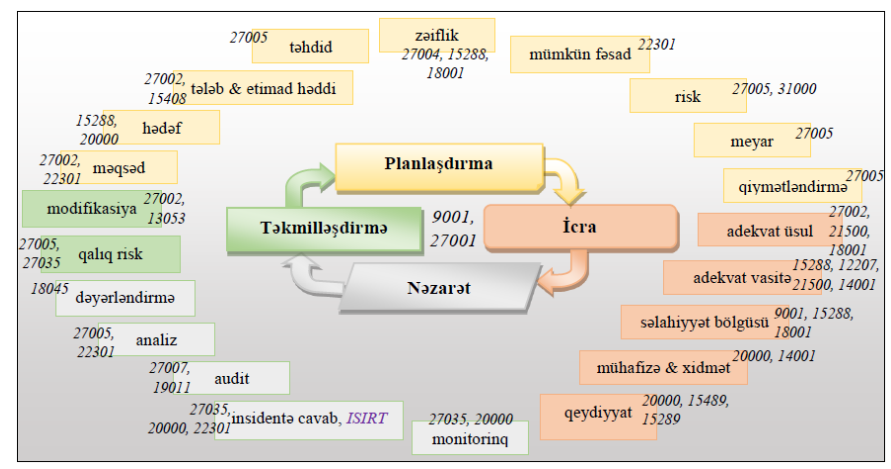

\section{IV. İNFORMASIYA TӘHLÜKӘSIZLIYININ \\ MENECMENTINDӘ STANDARTLARARASI ӘLAQӘLӘNDİRM PROBLEMLӘRİ}

\section{A. Sabab-natica asıllliqlarl}

İnformasiya təhlükəsizliyinin menecmenti üçün əsas prinsiplərdən biri - prosesli yanaşmadır, səbəb-nəticə asılılıqlarının nəzərə alınmasıdır. 


\section{“Informasiya tohlükosizliyinin aktual problemlori” \\ III respublika elmi-praktiki seminarı, 08 dekabr 2017-ci il}

Proses - konkret məqsəd ("objective") üçün lazım olan ("input") aktivi (informasiyanı, dəyəri, müraciəti) təqdim olunan ("output") aktivə (informasiyaya, dəyərə, xidmətə) çevirən, bir-biri ilə qarşılıqlı əlaqəsi olan fəaliyyət funksiyaları toplusudur.

\section{B. Koordinasiya}

İnformasiya təhlükəsizliyinin menecment proseslərinin sxemdə göstərilən müəyyən (çox) hissəsi üçün lazım olan ("input") informasiya digər standartlarla müəyyən olunan proseslərdən təqdim edilməli olan ("output") informasiyadır.

$\mathrm{Bu}$ səbəb-nəticə asılılıqlarını nəzərə alınması həm korporativ mühitdə və həmdə standartlaşma mühitində koordinasiya məsələsinin həll vasitəsidir.

\section{Standartlarin harmonizasiyasina zarurat}

ISO/IEC 27001 və 20000 standatlarında informasiya təhlükəsizliyinin menecmenti sistemi ("ISMS") və İTservislərin menecmenti sistemi ("SMS") arasında "maraqların münaqişəsi”"nə zəmin yaradan, bu sistemlərin inteqrasiyalı tətbiqinə maneə törədən kritik faktorlar aşağıdakılardır:

1) ISMS və SMS üçün müəyyən edilmiş əsas məqsədlərdəki fərqlər bu sistemlər arasında qarşılliqlı tamamlanma problemini yaradan ilkin faktordur:

- ISO/IEC-27001 informasiya təhlükəsizliyinə risklərin və insidentlərin menecmentinə imkan yaratmaq məqsədi daşıyır.

- ISO/IEC-20000 İT xidmətlərin effektif təchiz olunmasına əminliyi təmin etmək məqsədi daşıyır.

2) İnsident menecmentdə terminlərdəki uyğunsuzluq ISMS və SMS arasında sinxronizasiya problemini yaradan ilkin faktordur:

- insident - əvvəldən məlum olan va ya hələ məlum olmayan və böyük ehtimala malik riskin reallaşmasıdır;

- ISO/IEC-27001: İnformasiya təhlükəsizliyi insidenti biznes proseslərin davamlılığını pozmaq və ya nüfuzdan salmaq və informasiya təhlükəsizliyinə təhdid yaratmaq üçün böyük ehtimala malik olan bir və ya sistematik təkrarlanan bir neçə arzuolunmaz və ya gözlənilməz informasiya təhlükəsizliyi hadisəsidir.

- Təhlükəsizlik hadisəsi - təhlükəsizlik siyasətinin pozulması və ya təhlükəsizlik alətlərinin çatışmazlığı nəticəsində yaranan vəziyyətin və ya təhlükəsizlik baxımından əvvəl məlum olmayan situasiyanın aşkar edilməsidir, ifadəsidir.

(riski müəyyənetmə $\rightarrow$ insidenti aşkarlama $\rightarrow$ bisnesə fasadl qiymatlandirma)

- ISO/IEC-20000: İnsident - İT-xidmotin standart istismarına aid olmayan, bu xidmətin dayanaqıllı̆ının pozulmasına və ya keyfiyyət göstəricilərinin azalmasına gətirib çıxaran və yaxud çıxara bilən hər bir hadisədir.

- İnsidentin müxtəlif dərəcələrə bölünür: insidnet, çiddi insident, problem, məlum səhv və s. Konfiqurasiya vahidinin nasazlığı da insidentdir. (insidenti aşkarlama $\rightarrow$ problemi/sabəbi müəyyənetmə $\rightarrow$ xidmətə fasad qiymatlandirma)

3) Qiymətləndirilən risklərin mahiyyətcə müxtəlif olmas1 "ISMS" və "SMS" arasında maraqların izolyasiyası problemini yaradan ilkin faktordur:

- ISO/IEC-27001 informasiya təhlükəsizlyinə olan riskləri və onların biznes proseslər üçün təsirini müəyyən edir, biznes tərəfi bu risklərin mütləq sahibidirr;

- ISO/IEC-20000 isə yalnız "SMS" va İT xidmətlərə olan riskləri müəyyən edir, biznes tərəfi bu risklərin nadir hallarda sahibi olur.

ISO/IEC-27001 satndartı və ISMS üşün mühüm olan müəyyən terminlər ISO/IEC-20000 va SMS üçün kənarda qalır, istifadə olunmur:

- informasiya aktivi;

- təhdid, hücum;

- biznes davamlllı̆̆ ("business continuity");

- təhlükəsizlik meyarları və alətləri ("control”);

- hadiso;

- informasiya təhlükəsizliyi hadisəsi;

- informasiya təhlükəsizliyi üzrə insident menecment;

- informasiya təhlükəsizliyi riski;

- risk menecmenti, riski qəbuletmə, risk analizi, riski qiymətləndirmə, riskin emalı və s.

\section{STANDARTLARARASI ӘLAQӘLӘNDIRMӘ ÜZRӘ TOKLIFLOR}

ISO/IEC/IEEE-15289 standartında prosesli yanaşma prinsipinə uyğun olaraq, proqram təminatı vasitələrinin (ISO/IEC-12207) və İT sistemlərin (ISO/IEC-15288) həyat tsilki proselərinə, ITT xidmətlərin menecmenti (ISO/IEC-20000) proseslərinə tətbiq olunan model həmçinin ISO/IEC-27001 və digər əlaqəli menecment standartları arasında səbəb-nəticə əlaqələrinin təyin olunması üçün də tətbiq olunarsa, bu məqalədə qeyd olunan problemlərin həll olunmasına və aşağıda göstərilən nəticələrin əldə olunmasına standart zəmin yaradıla bilər:

- Menecment standartları va sistemləri arasında səbəbnəticə asılılıqlarının dəqiqləşdirilməsi və uzlaşdırmanın təmin edilməsi;

- Koporatv mühitdə müxtəlif sahələrin menecment sistemləri üzrə səlahiyyətlər bölgüsünün və koordinasiyanın inteqrasiyası (general koordinasiya);

- İnformasiya təhlükəsizliyinin menecmenti standarlarının əlaqəli standartlarla harmonizasiyas1;

- "ISMS" (ISO/IEC-27001) və "SMS" (ISO/IEC-20000) arasında "maraqların münaqişəsi"nin "maraqların uzlaşdırılması"na transfer məsələsinin həlli. 
CODVӘL 1. KORPORATIV FOALIYYOTIN, INFORMASIYA TəHLÜKOSIZLIYININ, IT-SISTEMLORIN və ITT-XIDMOTLORIN MENECMENT MəRHӘLӘLӘRİ ARASINDA UZLASMA

\begin{tabular}{|c|c|c|c|}
\hline $\begin{array}{c}\text { Korporativ } \\
\text { faaliyyətin } \\
\text { menecment } \\
\text { mərhələri } \\
\text { ISO-9001 } \\
\end{array}$ & $\begin{array}{c}\text { İnformasiya } \\
\text { təhlükəsizliyinin } \\
\text { menecment } \\
\text { mərhələləri } \\
\text { ISO/IEC-27001 } \\
\end{array}$ & 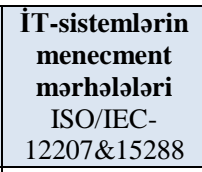 & $\begin{array}{l}\text { İT-xidmotlərin } \\
\text { menecment } \\
\text { mərhələri } \\
\text { ISO/IEC-20000 }\end{array}$ \\
\hline \begin{tabular}{|c|} 
Korporativ \\
fəaliyyəti \\
planlaşdırma \\
Qərar qəbuletmə
\end{tabular} & \begin{tabular}{|c|} 
Korporativ fəaliyyət \\
proseslərinin \\
informasiya \\
təhlükəsizliyini \\
planlaşdırma \\
Qərar qəbuletmə \\
\end{tabular} & 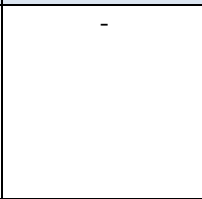 & - \\
\hline \multirow[t]{3}{*}{\begin{tabular}{|c|} 
Plan və qərarları \\
həyata keçirmə \\
Resurslarla \\
təminat \\
Qeydiyyatlar \\
\end{tabular}} & $\begin{array}{c}\text { Mühafizəni həyata } \\
\text { keçirmə } \\
\text { Risklərə adekvat } \\
\text { resurslarla təminat } \\
\text { Qeydiyyatlar }\end{array}$ & \begin{tabular}{|l} 
Korporativ \\
fəaliyyətin İT \\
üzrə tələbatını \\
Planlaşdırma \\
Texniki tələblər/ \\
Layihə \\
Təchizat/ İşləyib \\
hazırlama \\
Quraşdırma \\
Verifikasiya \\
Təlim \\
Validasiya \\
İstismara tətbiq \\
\end{tabular} & \\
\hline & & IT-xidmətlər & $\begin{array}{l}\text { IT-xidmətləri } \\
\text { planlaşdırma } \\
\text { IIT-xidmətləri } \\
\text { həyata keçirmə } \\
\text { Qeydiyyatlar } \\
\text { IT-xidmət nəticə- } \\
\text { lərinin monitorinqi } \\
\text { Hesabat/ } \\
\text { Dəyərləndirmə } \\
\text { IT-xidmətləri } \\
\text { davamlı } \\
\text { təkmilləşdirmə } \\
\end{array}$ \\
\hline & & $\begin{array}{l}\text { Istismardan } \\
\text { çıxarma } \\
\text { Utilizasiya } \\
\end{array}$ & - \\
\hline $\begin{array}{c}\text { Audit } \\
\text { Analiz/ } \\
\text { Dəyərləndirmə }\end{array}$ & $\begin{array}{c}\text { Monitorinq } \\
\text { Analiz/ } \\
\text { Dəyərləndirmə }\end{array}$ & & \\
\hline \begin{tabular}{|c|} 
Korporativ \\
fəaliyyəti davamlı \\
təkmilləşdirmə
\end{tabular} & $\begin{array}{c}\text { İnformasiya } \\
\text { təhlükəsizliyini } \\
\text { davamlı } \\
\text { təkmilləşdirmə }\end{array}$ & & \\
\hline
\end{tabular}

\section{ӘDӘBIYYYT}

[1] ISO/IEC-27001:2013 "Information technology. Security techniques. İnformation security management systems. Requirements", 2013. 23 p.

[2] ISO-9001 "Quality management systems. Requirements", 2015. 29 p.

[3] ISO/IEC-12207 "Systems and software engineering. Software life cycle processes", 2017, $145 \mathrm{p}$.

[4] ISO/IEC/IEEE 15288 "Systems and software engineering -- System life cycle processes", 2015. $108 \mathrm{p}$.

[5] ISO/IEC/IEEE-15289 "Systems and software engineering. Content of life cycle information products (documentation)", 2011.

[6] ISO/IEC-20000-1 "Information technology -- Service management -Part 1: Service management system requirements", 2011. 26 p.

[7] ISO/IEC-27013 "Information technology. Security techniques. Guidance on the integrated implementation of ISO/IEC-27001 and ISO/IEC20000-1", 2015. 39 p.

[8] COBIT 5 ("Control Objectives for Information and Related Technologies”), 2012

\section{MAP OF HARMONIZATION OF INFORMATION SECURITY MANAGEMENT STANDARDS WITH RELATED STANDARDS: SUGGESTIONS}

Elchin A.Aliyev ${ }^{1}$, Yadigar İmamverdiyev ${ }^{2}$

${ }^{1,2}$ Institute of Information Technology of ANAS, Baku, Azerbaijcan,

Ielchinaa@gmail.com,2yadigar@lan.ab.az.

Abstract - This article sets out the problems of coordination between standards and information security management systems and management standards and systems of other related areas. For this it identifies standards and systems for managing information security and other related areas, and these control processes are classified according to the PDCA model and are studied. The paper also identifies problems of harmonization of information security management standards with relevant standards, including causeeffect relations and incompatibilities in terminology. Solutions for the transformation of "conflict of interest" into "communication of interests" are provided between ISMS (ISO / IEC-27001) and SMS (ISO / IEC-20000).

Keywords - information security; management system; management standards; PDCA model; process approach; harmonization of standards 